\title{
VelHice Na ANTIGÜIDAde
}

\section{Fernanda Messeder Moural}

PARKIN, T.G. Old age in the Roman world: a cultural and social bistory. Ancient Society and History series. Baltimore: The Johns Hopkins University Press. 2003. 495pp. ISBN: 0-8018-7128-X.

Pensar a velhice na Antigüidade Clássica, mormente segundo a perspectiva romana, significa, em geral, evocar uma atitude de deferência cujos alicerces residem, sobretudo, na sabedoria adquirida com o passar dos anos pela experiência do senex e indicar como a ele, ao mais velho, cabe aconselhar e arbitrar tanto sobre questões familiares sob a autoridade do pater familias quanto sociais, como indica 0 empréstimo de sua raiz à formação da palavra senatum (Cic., De Or., vi,19).

Parkin, no entanto, busca justamente uma outra abordagem: a partir da literatura, de documentos epigráficos, legais e de papiros, propõe-se a questionar se a atitude reverenciosa aos mais velhos se verificava de fato e, neste caso, sob quais circunstâncias.

Quatro partes constituem seu livro: na primeira (pp. 13-89), propõe-se a definir o que significava ser velho para os romanos; na segunda (pp. 91-189) e na terceira (pp. 191235), discorre sobre como eram regidas as vidas pública e privada do velho, respectivamente utilizando como recorte histórico sobretudo 0 período augustano, para então, na parte final (pp.237-276), tecer comentários sobre a marginalidade da posição social do velho na
Roma antiga. Acrescentam-se a elas tabelas demográficas em apêndice, fio condutor de sua pesquisa, notas muito bem cuidadas (pp. 309438) e vasta bibliografia (pp. 439-482).

Logo na introdução (pp.1-12), o autor chama atenção para o fato de que irá conduzir um estudo sincrônico, pois, segundo ele, a diacronia lhe traria o indesejável resultado de um catálogo de nomes e definições para a velhice através de alguns séculos. Adverte igualmente o intento de voltar-se não para o velho como um segmento social, ao qual poderia comparar-se o jovem e 0 adulto, mas para o status individual de que 0 velho desfrutava na sociedade romana. Cabe observar que tal objetivo é alcançado somente em parte, já que em diversos momentos, como o próprio autor observa, o velho é inevitavelmente analisado como um grupo homogêneo, estando ligado a extratos sociais.

Nos primeiros três capítulos, Parkin busca determinar qual faixa etária teria comportado os velhos, tomando como referência os estágios que compõem os corpora Hipocrático e Varroniano, o registro existente de epitáfios africanos, bem como depoimentos, dentre outros autores, de Lucrécio, Marcial, Cícero e Salústio. Contudo, discordam entre si de tal maneira as

1 Mestranda do Programa de Pós-Graduação em Letras Clássicas/UFRJ. Bolsista Capes. 
fontes, que Parkin, após estabelecer tabelas demográficas em que figuram taxas de natalidade e mortalidade, admite como provável expectativa de vida a idade de sessenta anos e conclui que a idade per se não parecia ser de grande valia senão para a regulação de alguns ofícios, cabendo utilizar mais acertadamente a gradação de puer (menino), iuuenis (jovem) e senex (velho). Por fim, Parkin analisa algumas obras literárias como De senectute de Cícero, cartas de Sêneca a Lucílio e algumas sátiras de Juvenal com o intuito de apresentar diferentes discursos apreciativos sobre a velhice e qual contexto político-social reverberavam, sem deixar de compará-las com obras de autores como Plutarco e Aristóteles.

Nos capítulos 4 a 6, dando início à segunda partedo livro, Parkin examinadados legaisesociais da velhice, sua real participação na vida pública romana, além de discutir a autoridade exercida pelo senex no senado e que tipo de prestígio e honra the eram peculiares, afirmando, por fim, que aos homens de quarenta a cinqüenta anos, não aos senes, como se aponta de costume, eram atribuídos os encargos do senado. Parteentão para a análise de documentos administrativos e jurídicos principalmente do Egito romanoem que constam declarações de censos, oestabelecimento de idades mínimas para o exercício de determinados cargos e de idades em que os senes passavam a estar isentos tanto do pagamento de taxas quanto de suas obrigações públicas como provade alguns benefícios que os mais velhos recebiam.

Nos dois capítulos seguintes, compondo a terceira parte do livro, Parkin passa a abordar a vida privada dossenes segundo leis que arbitravam sobre o estado civil dos romanos, dentre elas a Lex Iulia, que impedia o recebimento de qual quer fração da herança familiar a um homem solteiro e a Lex Papia, que determinava a idade de sessenta anos para os homens e de cinquienta para as mulheres como idade limite para terem filhos. Apresentamse, então, diversas considerações sobre as expectativas da relação entre pais efilhos, das quais umase mostra principal, a saber, a que distingue as sociedades grega e romana no seguinte ponto: se para os gregos a obrigatoriedade de os filhos se responsabilizarem tanto por cuidar de seus pais quanto por thes fornecer honras funerárias era assegurada pela legislação, como retribuição dos cuidados que lhes foram oferecidos quando crianças, para os romanos tais deveres estavam assegurados pelo código moral e ético da pietas.

Na quarta e última parte de seu livro, Parkin reitera de modo mais explícito o que vinha indicando ao longo dos capítulos anteriores, i.e., que os romanos, uma vez senes, já não ocupavam, salvo exceções, qualquer função ativa na sociedade, estando, portanto, à margem dela. Desse modo, Parkin retira grande parte da aura que normalmente envolve osenex romano, baseando-se em registros históricos e literários, e o contextualiza tanto no domínio familiar quanto no social de forma admirável. 